\title{
Detection of bacterial antigens by means of sensitized guinea-pig ileum
}

\author{
By F. E. BUCKLAND* \\ Microbiological Research Establishment, Porton, Salisbury, Wilts
}

(Received 21 April 1960)

\section{INTRODUCTION}

The original experiments of Schultz (1910) were concerned with the reactions of isolated portions of intestine of guinea-pigs (previously sensitized by a particular antibody), when exposed to the action of the homologous specific antigen. Such sensitized isolated muscle, suspended in a bath of Ringer's solution, was found to contract far more vigorously in the presence of the specific antigen than similar pieces of smooth muscular material from normal animals. Schultz's observations were confirmed and very much extended by Dale (1913), who showed by an elegantly improved technique, in which one horn of the guinea-pig's uterus was substituted for the isolated piece of intestine, that the sensitivity of the reaction could be increased to a remarkable degree; the reaction was also sharply specific.

In spite of the voluminous literature surrounding the Schultz-Dale reaction comparatively little attention has been devoted to the reaction in relation to bacterial antigens in particular. Avery \& Tillett (1929) obtained type-specific reactions in guinea-pigs passively sensitized with rabbit precipitating serum against types 2 and 3 pneumococci; $5 \mu \mathrm{g}$. proved fatal, while $2 \mu \mathrm{g}$. gave rise to signs of distress. Morgan (1932), working with the polysaccharide of Shiga's dysentery bacillus, obtained fatal shock in passively sensitized animals with $15 \mu \mathrm{g}$. injected intravenously. Towcsik (1927) in his experiments with the specific substance from Aerobacter aerogenes, employing the guinea-pig uterus technique, found he got contractions with as little as $0.2 \mu \mathrm{g} . / \mathrm{ml}$. Kabat \& Landow (1942) pointed out that anaphylactic reactions can occur in actively sensitized animals without demonstrable antibody, or may be produced by injections of sera in which no antibody could be detected by the usual in vitro tests. Up to that time very little had been known about the actual dose of antibody that must be present in the tissues before fatal anaphylactic shock could occur. Using crystalline egg albumen, they showed that $0.03 \mathrm{mg}$. antibody $\mathrm{N}$ is sufficient to cause fatal shock in guinea-pigs if they are given $1 \mathrm{mg}$. antigen in the egg albumen system or $0.1 \mathrm{mg}$. polysaccharide in the Type 3 pneumococcus system.

With complement-fixation tests $0 \cdot 2-1 \cdot 0 \mu \mathrm{g}$. is about the limit of sensitivity when complete fixation is taken as the end-point; it is recognized that precipitation and agglutination tests are less sensitive than complement fixation. The optimum proportions for anaphylactic response differ from those in the usual immunoWilts. 
logical tests: in the precipitation reaction only about $0.003 \mathrm{mg}$. of egg albumen $\mathrm{N}$ is required to precipitate all of the 0.03 antibody $\mathrm{N}$ used to sensitize the guinea-pig, and for optimal anaphylactic effect $1 \mathrm{mg}$. egg albumen $(0.16 \mathrm{mg}$. N). Anaphylactic reactions have their optima at the extreme antigen excess of the precipitation zone where soluble antigen-antibody compounds are formed.

The experiments reported in this paper were undertaken with the object of determining the smallest amount of a bacterial antigen that would cause a significant anaphylactic response in isolated guinea-pig ileum of animals appropriately sensitized passively. Some non-bacterial antigens were included for comparison. The consistency of results obtained with a range of antigen and antibody concentrations was also investigated.

\section{MATERIALS AND METHODS}

\section{Antigens}

The following antigen preparations were used:

Salmonella typhi. Degraded polysaccharide hapten derived from ' $O$ ' somatic antigen of $S$. typhi ' 901 '.

Salmonella typhimurium. Degraded polysaccharide hapten derived from ' $O$ ' somatic antigen of S. typhimurium.

Pasteurella pestis. Acetone dried disintegrated whole culture.

Shigella dysenteriae (Shiga). Degraded polysaccharide hapten derived from the somatic antigen (Davies, Morgan \& Record, 1955).

Bacillus anthracis. A substance obtained from the alum precipitate of culture filtrate freed from alum and dialysed.

Brucella suis. Acetone dried disintegrated whole culture.

The preparations of degraded polysaccharide appeared homogeneous by electrophoresis and ultracentrifugation and were thought to be at least $95 \%$ pure.

\section{Antisera}

Bacillus anthracis. Guinea-pigs were given ten doses at fortnightly intervals of $1 \mathrm{ml}$. of a filtrate of an anthrax culture, alum precipitated and resuspended in 1/5 of the original volume.

Pasteurella pestis. Rabbits were given eighteen injections at bi-weekly intervals of Past. pestis Tjiwidej grown at $28^{\circ} \mathrm{C}$.

The remaining antisera were standard agglutinating sera prepared at the David Bruce Laboratory for routine use in the Army. They comprised Salmonella typhi 0 (titre 1/8000); S. paratyphi A O (titre 1/1280); S. paratyphi B O (titre 1/1280); Shigella dysenteriae (Shiga) (titre 1/1280); Brucella melitensis (titre 1/400) and Br. abortus (titre 1/640).

It was not feasible to determine the antibody nitrogen content of all these sera but that of the $S h$. dysenteriae serum was $46 \mu \mathrm{g}$. $/ \mathrm{ml}$. This figure for a serum with an agglutination titre of $1 / 1280$ is consistent with the results obtained by Hrubesova, Askonas \& Humphrey (1959) for an antiserum prepared from the O-strain of S. typhi-murium, Glasgow. 


\section{Sensitization of tissues}

Guinea-pigs were passively sensitized by the intraperitoneal injection of $2 \mathrm{ml}$. of the appropriate serum $48 \mathrm{hr}$. before being killed for the test.

\section{Organ bath technique}

Pieces of ileum from 175 to $250 \mathrm{~g}$. sensitized guinea-pigs were suspended in Tyrode solution at $37^{\circ} \mathrm{C}$. under a tension of $0.5 \mathrm{~g}$. in a $2 \mathrm{ml}$. organ bath apparatus of the type described by Boura, Mongar \& Schild (1954). The bath was aerated by bubbling oxygen through a sintered glass plate. The solutions used were those described by Adam, Hardwick \& Spencer (1954). The lever recording system gave a magnification of 6.5 and a movement of $1 \mathrm{~cm}$. on the tracing was regarded as a significant response.

\section{RESULTS}

The first series of experiments is summarized in Table 1 .

It was assumed that $2 \times 10^{12}$ vegetative organisms weighed $1 \mathrm{~g}$. dry weight and that $5 \%$ of an organism was specific substance (D. A. L. Davies, personal communication).

Table 1. Least amount of various antigens producing specific response in sensitized ileum

Sensitizing serum

( $2 \mathrm{ml}$. intraperitoneally)

$\overbrace{\begin{array}{c}\text { Prepared } \\ \text { against }\end{array}}^{\begin{array}{c}\text { Obtained } \\ \text { from }\end{array}} \begin{gathered}\begin{array}{c}\text { Agglutination } \\ \text { titre }\end{array} \\ \text { natring }\end{gathered}$

$\begin{array}{clc}\begin{array}{c}\text { Bovine plasma } \\ \text { albumen }\end{array} & \text { Guinea-pigs } & - \\ \begin{array}{c}\text { Purified egg } \\ \text { albumen }\end{array} & \text { Guinea-pigs } & - \\ \text { Past. pestis } & \text { Rabbits } & -\end{array}$

\section{B. anthracis Rabbits}

Sh. dysenteriae Rabbits

S. typhi

Rabbits

S.paratyphiA Rabbits

S.paratyphiB Rabbits

Br. melitensis Rabbits
Antigen preparation

Bovine plasma albumen

Purified egg albumen

Past. pestis

Acetone dried disinte-

grated whole culture

B. anthracis

Antigen preparation (purity not determined)

1280

Sh. dysenteriae

Purified degraded

polysaccharide

S. typhi

('O')

Purified degraded polysaccharide

1280 S. paratyphi $A$

1280

('O')

400 Acetone dried disintegrated whole culture

S. typhimurium

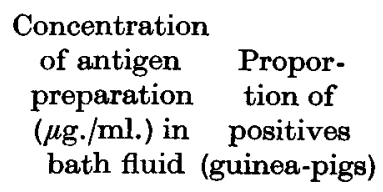

$\begin{array}{cc}1 \cdot 0 & 1 / 3 \\ 0 \cdot 1 & 1 / 3 \\ 1 \cdot 0 & 2 / 4 \\ & \\ 1 \cdot 0 & 2 / 3\end{array}$

0.01

$2 / 7$

$1 \cdot 0$

$2 / 8$

$10 \cdot 0$

$0 \cdot 01$ 
It can be seen that the method was at least as sensitive in detecting bacterial antigens as in detecting animal proteins.

$B r$. suis material reacted poorly, but this may have been due to the fact that homologous serum was not used. The amount of $S h$. dysenteriae and S. typhimurium antigen which was detected was equivalent to about $4 \times 10^{5}$ organisms $/ \mathrm{ml}$.

The antigens did not desensitize the ileum in the concentrations used nor were reactions obtained with heterologous antigens.

Further experiments were done to find the degree of consistency obtained with a range of antigen or antibody concentrations. The antibody nitrogen content of the Sh. dysenteriae serum used was $46 \mu \mathrm{g}$. $/ \mathrm{ml}$. (Table 2).

From the first five entries it is clear that with $1 \mu \mathrm{g}$. antigen $/ \mathrm{ml}$. a positive result may be obtained with amounts of antibody as little as $2 \cdot 3 \mu \mathrm{g} . / \mathrm{N}$ equivalent contained in $0.05 \mathrm{ml}$. of serum.

Table 2. Reaction of ileum of passively sensitized guinea-pigs to Sh. dysenteriae

\begin{tabular}{|c|c|c|c|c|}
\hline \multirow{2}{*}{$\begin{array}{c}\text { Sensitizing } \\
\text { dose of serum } \\
\text { (ml.) }\end{array}$} & \multirow{2}{*}{$\begin{array}{l}\text { Concentration } \\
\text { of antigen } \\
\text { in bath } \\
(\mu \mathrm{g} . / \mathrm{ml} .)\end{array}$} & \multicolumn{3}{|c|}{ Proportion of positives } \\
\hline & & Guinea-pigs & Pieces & of ileum \\
\hline 0.05 & $1 \cdot 0$ & $5 / 7 *$ & $9 / 28^{*}$ & $32 \%$ \\
\hline $0 \cdot 1$ & 1.0 & $6 / 7$ & $15 / 25$ & $60 \%$ \\
\hline 0.5 & $1 \cdot 0$ & $2 / 2$ & $5 / 8$ & $62 \%$ \\
\hline $1 \cdot 0$ & $1 \cdot 0$ & $3 / 3$ & $6 / 8$ & $75 \%$ \\
\hline $2 \cdot 0$ & $1 \cdot 0$ & $17 / 17$ & $53 / 63$ & $84 \%$ \\
\hline $2 \cdot 0$ & 0.5 & $3 / 4$ & $7 / 14$ & $50 \%$ \\
\hline $2 \cdot 0$ & $0 \cdot 1$ & $1 / 3$ & $1 / 6$ & $16 \%$ \\
\hline
\end{tabular}

However, the results were more uniformly positive when tissue from guineapigs, given larger volumes of serum, were used; $2 \mathrm{ml}$. were therefore used in the last two experiments.

With $2 \mathrm{ml}$., less than $1 \mu \mathrm{g} . / \mathrm{ml}$. antigen no longer gave a regularly positive reaction.

\section{DISCUSSION}

In the course of immunological studies on egg albumen it was shown (Kabat \& Landow, 1942) that $1 \mathrm{mg}$. of this antigen is required to give fatal anaphylactic shock in guinea-pigs and $0 \cdot 2-1 \mu \mathrm{g}$. is required to give full fixation in a standard complement-fixation test.

In the experiments with $S h$. dysenteriae we found consistently positive results at dilutions equivalent to the limit of sensitivity of the complement-fixation test in the egg albumen system; irregular results were obtained to a substantially higher dilution.

Since this work was completed an extensive study by Ishizaka, Ishizaka \& Sugahara (1956) has appeared with which our results are in agreement. 


\section{SUMMARY}

Using a Dale organ bath and the ileum of passively sensitized guinea-pigs a specific sensitive reaction with as little as $1 \mu \mathrm{g} . / \mathrm{ml}$. of disintegrated whole cultures of various bacteria and $0.01 \mu \mathrm{g} . / \mathrm{ml}$. of purified Sh. dysenteriae and $S$. typhimurium polysaccharides was obtained.

More detailed study showed that $1 \mu \mathrm{g} . / \mathrm{ml}$. of $S h$. dysenteriae degraded polysaccharide derived from the $\mathrm{O}$ antigen could be detected with consistency. Lower concentrations gave irregular results.

My thanks are due to the David Bruce Laboratory for supplying the antisera and the bacterial suspensions, to Prof. W. T. J. Morgan of the Lister Institute of Preventive Medicine for the antibody nitrogen determinations, to DrD. A. L. Davies of the Microbiological Research Establishment, Porton, for the antigen preparations and to Corporals G. Willis and P. Brown, R.A.F., for much careful work in day to day experiments.

\section{REFERENCES}

Adam, H. M., Hardwick, D. C. \& Spencer, K. E. V. (1954). Brit. J. Pharmacol. 9, 360. Avery, O. T. \& TIllett, W. S. (1929). J. exp. Med. 49, 251.

Boura, A., Mongar, J. \& Schild, H. O. (1954). Brit. J. Pharmacol. 9, 24.

Dale, H. H. (1913). J. Pharmacol. 4, I67.

Davies, D. A. L., Morgan, W. T. J. \& Record, B. R. (1955). Biochem. J. 60, 290.

Hrubesova, M., Askonas, B. A. \& Humphrey, J. H. (1959). Nature, Lond., 183, 97.

Ishizaka, K., Ishizaka, T. \& Sugahara, T. (1956). Jap. J. med. Biol. 9, 191.

KaBAT, E. A. \& LANDOW, H. (1942). J. Immunol. 44, 69.

Morgan, W. T. J. (1932). Brit. J. exp. Path. 13, 342.

Schultz, W. H. (1910). J. Pharmacol. 2, 221.

Towcsik, J. (1927). Proc. Soc. exp. Biol., N.Y., 24, 810. 